\title{
Implementation of the Assets and Liabilities Structure's Ratios in a Company Activity Evaluation
}

\author{
Elena Galkina $^{1 *}$ \\ ${ }^{1}$ Federal State Budgetary Educational Establishment of Higher Education "The Orel State University of Economics \\ and Trade, Russia \\ *Email: gev578@mail.ru
}

\begin{abstract}
Presented in this article the main financial analysis ratios allow evaluating the structure of the company's assets and liabilities. For each reviewed financial ratios the economical determination is given alongside the determination procedure and designation in the international analysis. The correlation between assets and liabilities structure indicator and multipliers' indicators of a company's assets and liabilities is shown. The formation method of all the indicators from the financial statements, which could be included as calculation variables, is provided. These ratios may be determined on the base of financial statements. Therefore, they are accessible not only for the company's internal analysis but for the external one. Adopted designations in formulas are given based on the International accounting standards of financial statements.
\end{abstract}

Keywords: Assets, Analysis, Coefficient, Liabilities, Financial statement.

\section{INTRODUCTION}

World economic practice generally considers ratios determined based on financial statements. The ratios are used in different purposes. Thus, Bisaeva Z.M. and Makkaeva R.S.A. use them in general financial analysis [1]. Authors Novoselov S.N. and Ivanova A.A. explore the company's financial condition [2]. The works of Ghyniyatullina A.A. are dedicated to capital analysis based on ratios [3,4]. Researcher Savchenko N.L. studies financial risks using ratios [5]. Pashnanov E.L. and Obgenova L.A. explore the process of making decisions regarding financial investments [6]. In international publications, the ratio analysis is used as an additional instrument, e.g. Shygun, M.M., Ostapiuk, N.A., Zayachkivska, O.V., and Goylo, N.V. use it for solving the accounting liquidity management problem [7]. Galbraith John W., Zinde-Walsh Victoria studied the econometric models building process [8]. Kruglyak Z.I. and Shvireva O.I. consider the ratios in contexts of a financial statements' structure. Karshalova A.D., Markhayeva B., Aitkazina M.A., and Mukushev A. emphasize attention on management accounting [10].

Shygun, M.M., Ostapiuk, N.A., Zayachkivska, OV. and Goylo, N.V. point the importance of assets and liabilities' structure statements data for managing company: "It is important to avoid manipulating balance sheets and artificially enhancing their liquidity by changing the structure of assets" ${ }^{1}$ [7].

At the same time, ratios are a visual presentation of financial information including the company's assets and liabilities structure, and thus deserve further development. In the economic literature, there are different names for coefficients and their abbreviations depending on the author's position and the variant of used English. Generally, used in financial statements, based on

\footnotetext{
${ }^{1}$ Quoted as per original. Translation: "It is important to avoid manipulation with balance sheets and artificially enhanced liquidity by shifting assets' structure.
} 
the International Standards of accounting and financial statements, determinations are used.

\section{RESEARCH METHODOLOGY}

The object of this work is the generalization of assets and liabilities structure's ratios composition and their comparison to highlight the possibilities of using this group of ratios in evaluating the company activity. Such an approach is focused on the expansion of the financial ratios potential as a management decision making instrument.

Research phases include a generalization of the assets and liabilities ratios composition and structure information, and developing a composite factor model for use in the evaluation of a company activity, which is based on the information about assets and liabilities structure, and model practical approval.

The methods used consist of general scientific (analysis and synthesis, abstraction and specificity, modeling) and special methods (coefficient method and factor analysis method).

The company accounting (financial) statement information has been used as analytical information.

\section{RESEARCH RESULT}

Asset structure ratios. This ratios reflects relation of different kind of assets. Given indicators group may be informative for the primary evaluation of property capabilities of a company.

Current assets-to-non-current assets ratio (CNR) shows how many rubles (or other units of functional currency, if it is not a ruble) of current assets per one ruble of non-current assets - formula (1):

$$
\mathrm{CNR}=\frac{\text { Current_assets }}{\text { Non }- \text { current_assets }},
$$

where:

Current_assets - current assets,

Non-current_assets - non-current (capital assets).

Non-current assets -to- current assets ratio (NCR) the inverse of the CNR ratio - formula (2):

$\mathrm{NCR}=\frac{\text { Non }- \text { current_assets }}{\text { Current_assets }}$

NCR equals $1 /$ CNR.

If a detailed analysis is required, for different kinds of assets other ratios can be calculated.

$$
\mathrm{CAR}=\frac{\text { Current_assets }}{\text { Total_assets }},
$$

where:

Total_assets - total assets.

The ratio of non-current assets to total assets ratio $(N A R)$ - formula (4):

$\mathrm{NAR}=\frac{\text { Non }- \text { current_assets }}{\text { Total_assets }}$

Total sum of the CAR and NAR ratios equals 1 .

For more detailed analysis, any of the asset items ratios could be calculated.

Liabilities and equity ratios, leverage/gearing ratios. This ratios reflect relation of different types of liabilities and are used for primary evaluation of company financing sources.

Debt-to-equity ratio (DER) - characterizes the quotient of dividing liabilities by the company's capital formula $(5)$ :

$\mathrm{DER}=\frac{\text { Total_liabilities }}{\text { Total_equity }}$,

where:

Total_liabilities - total liabilities

Total_equity - total equity.

Equity-to-debt ratio $(E D R)$ - characterizes the ratio of capital to liabilities of the company - formula (6):

$$
\mathrm{EDR}=\frac{\text { Total_equity }}{\text { Total_liabilities }}
$$

EDR equals 1/ DER.

Debt-to-debt and equity ratio (DDER) - characterizes the quotient of dividing liabilities to the company's liabilities and shows the level of financing of the company through borrowed funds - formula (7):

$$
\mathrm{DDER}=\frac{\text { Total_liabilities }}{\text { Total_liabilities_and_equity }},
$$

where:

Total_liabilities_and_equity - total liabilities and equity.

Equity-to-debt and equity ratio, EDER characterizes the quotient of dividing equity capital to the company's liabilities and shows the degree of financing the company from its own sources - formula (8):

$$
\mathrm{EDER}=\frac{\text { Total_equity }}{\text { Total_liabilities_and_equity }}
$$

Sum of DDER and EDER ratios is one. For a more 
detailed analysis, any of the liabilities items ratios could be calculated.

Assets and liabilities multipliers. This group of indicators is determined by the ratio of the total of assets (or liabilities, since they are equal to assets) to different items of assets and liabilities. These ratios show how many times the assets (liabilities) exceed the corresponding item, or how many monetary units of the asset (liability) are per one unit of its component. The most common indicators of this group are the following ratios.

Equity multiplier (EM) - formula (9):

$E M=\frac{\text { Total_assets }}{\text { Total_equity }}$

Lliabilities multiplier, (LM) - formula (10):

$L M=\frac{\text { Total_assets }}{\text { Total_liabilities }}$

Non-current assets multiplier (NM) - formula (11):

$$
\begin{aligned}
& \text { NM }=\frac{\text { Total_assets }}{\text { Non - current_assets }} \\
& \text { Current assets multiplier (CM) - formula (12): }
\end{aligned}
$$

$$
C M=\frac{\text { Total_assets }}{\text { Current_assets }}
$$

Financial ratios are used to make management decisions. Therefore, the structure of assets and liabilities should be considered with the performance targets of the organization. For commercial organizations, the purpose of the activity is to make a profit, and the relative profit indicators are profitability ratios.

At the same time, to make a management decision, a limited range of the most significant indicators that affect the target criteria is required. As the authors of the econometric models Galbraith John W., Zinde-Walsh Victoria note: "Often an investigator is interested in a single parameter or low-dimensional parameter vector (e.g. a treatment effect) in a regression model, rather than in the full set of regression coefficients"2[8].

Therefore, to evaluate the impact of the structure of assets and liabilities on the financial result of an organization the following return on assets (RA) model can be used - formula (13):

$\mathrm{RA}=\frac{\text { Net_profit }}{\text { Total_assets }}=$

${ }^{2}$ Quoted as per original. Translation: "Often the researcher is interested in one parameter or a vector of low-dimensional parameters (for example, the effect of a

$$
\begin{aligned}
& =\frac{\text { Net_profit }}{\text { Total_equity }} * \\
& * \frac{\text { Total_equity }}{\text { Non-current_assets }} * \\
& * \frac{\text { Non }- \text { current_assets }}{\text { Total_assets }}= \\
& =R E * M N * N A R \\
& \text { where: }
\end{aligned}
$$

$$
\begin{aligned}
& \text { Net_profit-net profit, } \\
& R E \text { - return on equity, }
\end{aligned}
$$

$M N$ is the multiplier of non-current assets to total (equity) capital.

This model connects four absolute indicators or relative indicators (coefficients). It can be used in factor analysis of the profitability of the total assets (total liabilities), for which the ratios of the structure of equity capital, assets, and liabilities are the factors.

Moment indicators (all of the above) can be calculated at the beginning and end of the year (as well as on the dates of interim financial statements) or on average for the year (then the average value of the numerator and the average value of the denominator are preliminarily calculated; another option is averaging the ratios at the beginning and end of the year).

The methodology for using the proposed model of return on assets based on empirical data in structuraldynamic factor analysis is demonstrated below. As an empirical base for illustrative purposes, we used the accounting indicators of JSC "Raduga" (Tambov region), available for the public on the website of the Center for Disclosure of Corporate Information [11]. The calculation results based on formula (13) are presented in Table 1.

Each moment indicator in Table 1 is calculated as the arithmetic mean of the values at the beginning and end of the year. Ratios are the fractions of one. As per model calculations, the return on assets for the reporting year increased compared to the baseline by 0.1846 , or $18.46 \%$. This improvement was due to the positive impact of the growth of the return on equity (impact $+18.78 \%$ ), a decrease of the multiplier of non-current assets by equity (impact $+0.24 \%$ ), a decrease in the share of non-current assets in total assets (impact $+0.13 \%$ ) and the negative influence of the interaction of factors (impact $-0.69 \%$ ). Comparison of the results achieved with the planned indicators for the same period allows concluding the degree of achievement of the goals of financial

treatment) in the regression model, but not the full set of regression coefficients." 
Table 1. Template of the table of factor analysis of return on assets based on a three-factor model of the structure of assets and liabilities

\begin{tabular}{|c|c|c|c|}
\hline Indicators & 2018 & 2019 & Absolute change \\
\hline Net profit, thousand rubles. & -14946 & 12528 & 27474 \\
\hline Total assets, thousand rubles. & 149216 & 148375 & -841 \\
\hline Total equity, thousand rubles. & 28791 & 27582 & -1209 \\
\hline Non-current_assets, thousand rubles & 114820 & 112680 & -2140 \\
\hline RE & -0.5191 & 0.4542 & 0.9733 \\
\hline $\mathrm{MN}$ & 0.2507 & 0.2448 & -0.0060 \\
\hline NAR & 0.7695 & 0.7594 & -0.0101 \\
\hline RA & -0.1002 & 0.0844 & 0.1846 \\
\hline \multicolumn{4}{|l|}{ Influence on RA: } \\
\hline 1) return on equity (IRE) & \multicolumn{2}{|c|}{$\begin{array}{l}\text { Impact calculation: RE19 * MN18 * NAR18-RA18 } \\
\text { Years are represented by numeric indexes }\end{array}$} & 0.1878 \\
\hline $\begin{array}{l}\text { 2) the multiplier of non-current assets by } \\
\text { total (equity) capital (IMN) }\end{array}$ & \multicolumn{2}{|c|}{$\begin{array}{l}\text { Impact calculation: RE18 * MN19 * NAR18-RA18 } \\
\text { Years are represented by numeric indexes }\end{array}$} & 0.0024 \\
\hline $\begin{array}{l}\text { 3) the ratio of non-current assets to total } \\
\text { assets (INAR) }\end{array}$ & \multicolumn{2}{|c|}{$\begin{array}{l}\text { Impact calculation: RE18 * MN18 * NAR19-RA18 } \\
\text { Years are represented by numeric indexes }\end{array}$} & 0.0013 \\
\hline $\begin{array}{l}\text { 4) interaction of factors (residual } \\
\text { influence) }\end{array}$ & \multicolumn{2}{|c|}{$\begin{array}{l}\text { Impact calculation: RA19-RA18-IRE-IMN-INAR } \\
\text { Years are represented by numeric indexes }\end{array}$} & -0.0069 \\
\hline
\end{tabular}

performance management for the analyzed period of time.

The proposed model of the profitability of assets allows us to assess the impact on the relative indicator of the profitability of the organization, the indicators of the structure of its assets and liabilities, and, thereby, by demonstrating the relationship between changes in the financial situation and changes in the company's financial results. This model calculations provide additional information for making management decisions about the achieved efficiency of the organization, which makes it possible to increase the efficiency of management by using these coefficients compared to management methods that do not take them into account.

\section{CONCLUSION}

Due to the simplicity of the calculation, the ratios are easy to interpret. Many ratios are highlighted in the theoretical and practical work on financial analysis. However, to assess certain areas of the organization's activities, the choice from the variety of ratios given in the literature should be based on the criteria of necessity (compliance with the purpose of the analysis) and sufficiency (elimination of duplication - each ratio should highlight a new aspect of the phenomenon under study). This is justified by the following reasons: some ratios are inverse to each other or add up to one; several multielement ratios included different mathematical operations in the formula are difficult to interpret; some of the ratios may be unmanageable due to the impossibility of controlling the initial data (then, in a situation of limited time for making a decision, one should focus on the indicators could be changed). Therefore, in a certain practical analysis situation, the set of estimated ratios should be determined individually, considering general formalized recommendations.

\section{REFERENCES}

[1] Z.M. Bisaeva, R.S.A. Makkaeva, Financial ratios as a basis for research the state of financial reporting, Actual issues of the modern economy 4 (2020) 1721.

[2] S.N. Novoselov, A.A. Ivanova, The main financial indicators and ratios used in assessing the financial condition of the enterprise, In the collection: Innovations in the economy. Industry, education, finances. Collection of works of the III InterUniversity Scientific and Practical Conference, 2016, pp. 562-569.

[3] A.A. Giniyatullina, Key ratios of the analysis of the capital structure of an enterprise, In the collection: Actual problems of science in student research. Collection of materials of the VIII All-Russian student scientific and practical conference, 2018, pp. 356-358.

[4] A.A. Giniyatullina, Factors of formation of the capital structure of an enterprise and key ratios of its analysis, Bulatovskie chteniya Vol. 7 (2018) 182184. 
[5] N.L. Savchenko, The main criteria for financial risk in determining the level of financial leverage within the express analysis: Russian practice, Economic analysis: theory and practice 44(395) (2014) 58-66.

[6] E.L. Pashnanov, L.A. Obgenova, Analysis of the effectiveness of investments in securities, In the digest of articles: Models of economic development: theory and practice. The Works of the International Scientific and Practical Conference dedicated to the anniversary of Professor L.Ts. Badmakhalgayeva, 2015, pp. 37-39.

[7] M.M. Shygun, N.A. Ostapiuk, OV. Zayachkivska, N.V. Goylo, The influence of the classification of non-current assets as holding for sales on the liquidity of the company's balance sheet, Entrepreneurship and Sustainability Iss. 8(1) (2020) 430-441.

DOI: https://doi.org/10.9770/jesi.2020.8.1(30)

[8] Galbraith, John W., Zinde-Walsh, Victoria, Simple and reliable estimators of coefficients of interest in a model with high-dimensional confounding effects, Journal of Econometrics, October Vol. 218 Iss. 2 (2020) 609-632. DOI: https://doi.org/10.1016/j.jeconom.2020.04.031

[9] Z.I. Kruglyak, O.I. Shvyreva, Improving the Russian regulatory basis for international financial reporting standards - Based qualitative characteristics of financial information, Journal of Applied Economic Sciences Winter Vol. 12 Iss. 8 (2018) 2325-2338.

[10] A.D. Karshalova, B. Markhayeva, M.A. Aitkazina, A. Mukushev, Improvement of management accounting in the context of uncertainty and risks in the food retailing sector in the Republic of Kazakhstan, Journal of Applied Economic Sciences Vol. 12 Iss. 8 (2018) 2275-2282.

[11] Corporate information disclosure Centre, Official web-site, Search by companies. Retrieved from: https://www.e-disclosure.ru/portal/ 